\title{
Dietary aflatoxin exposure and impaired growth in young children from Kisumu District, Kenya: Cross sectional study
}

\author{
Sheila Adhiambo Okoth' and Mercy Ohingo ${ }^{2}$ \\ 1. University of Nairobi, P. O. Box 30197, Nairobi, Kenya \\ Tel. (O) 254-2-4449004 Ext.2470;(H) 254-2-2710845, 0733559250, \\ Fax 254-2-4449845 \\ 2. Maternal Child Health and Community Based Health Care Services \\ Kisumu Municipality, P. O. Box 105, Kisumu
}

\begin{abstract}
SUMMARY
Cereal grains are the basis of weaning gruel in Kenya yet they run a high risk of mycotoxin contamination. Children could be at a higher risk of dietary mycotoxin exposure than the rest of the population.. This paper presents information on the association between nutritional state of children and dietary exposure to aflatoxins in Kisumu District. Weaning flour samples were collected randomly from 242 households in Kisumu District, Kenya. A questionnaire was used to collect information, from mothers whose flour were sampled, on the types of weaning foods, handling and storage. The nutritional status of the children in question was assessed and their weight and height measured. The flour samples were analyzed for aflatoxins by thin layer chromatography. Cultural studies of the flour were also done. Thirty one percent of the children were malnourished. The number of children who were wasting and were being fed on flour contaminated with mycotoxins was highly significant $(P=0.002)$. Seventy samples $(29 \%)$ were positive for aflatoxins (concentration range $2-82 \mu \mathrm{g} / \mathrm{kg}$ ), some exceeding the advisory limit.
\end{abstract}

\section{[Afr J Health Sci. 2004; 11: 43-54]}

\section{Introduction}

Mycotoxins are metabolites of fungi which evoke pathological changes in man and animals. The most abundant mycotoxins associated with grains are the aflatoxins which are carcinogenic, immunotoxic, mutagenic and hepatotoxic causing growth retardation in animals [1]. Aflatoxins have been implicated in the etiology and pathogenesis of kwashiorkor and marasmus, and, have also been incriminated in the increased neonatal susceptibility to infection and jaundice [2]. For these reasons, mycotoxins come under regulatory limits in foods and feeds. However in Kenya, like in other developing countries, monitoring and enforcement of standards are rare. People are being exposed to unsafe levels of various mycotoxins, often in mixtures, and the consequences in terms of public health burden have been ignored. Aflatoxins have been incriminated in episodes of food poisoning that have been associated with serious morbidity and mortality in man and domestic animals in Kenya [3,4]. A part from these kind of surveys, hardly any data exists on routine analysis of food and foodstuffs for toxigenic fungi and their respective mycotoxins at various stages of processing in Kenya. Yet the effects of consuming small doses of mycotoxins over a long period of time may be of greater clinical importance. 
Aflatoxins have been detected in many grains, cereals nuts and legumes such as corn, wheat, sorghum, rice, soybean and peanuts. Aflatoxins have also been detected in cassava, liver, milk and milk products. Most of these foods form the basis of gruel used in the early months of weaning children in most African countries including Kenya. During the weaning period, the only other meal that the child is fed on apart from breast milk, is the grain based gruel. Mothers of malnourished children are also encouraged to feed their babies with gruel made from a mixture of grains such as maize, wheat, sorghum, legumes such as soy beans, green grams, cowpea; dried fish, groundnuts, sesame all ground together. Such mixtures, further, provide excellent media for the growth of fungi. This suggests that children may be more exposed to mycotoxins than the rest of the population and this could be the reason for increased cases of kwashiorkor and infant mortality in the country [5]. High exposure to aflatoxins could be the case throughout childhood in this region, affecting growth and development. This study assessed exposure to aflatoxins in relation to anthropometric measures in children in Kisumu District. This region was chosen as the study site because it is characterized with high temperatures (over $25^{\circ} \mathrm{C}$ ) and humidity ( varying between $40-89 \%$ in a day) which favor mould growth and therefore mycotoxin production. Mycotoxin contamination high risk foods are also commonly used in preparation of early childhood foods in the area. Further the district has a high incidence of kwashiorkor and the highest prevalence of absolute poverty, $64 \%$, in the country $[6,7]$.

\section{Materials and Methods Collection of samples}

Weaning flour samples were collected from Kisumu District between October 2000 and March 2002. A type of 3-stage random sampling design was applied in sample collection. Kisumu District is divided into four broad strata or divisions. The divisions are further divided into locations. Villages were chosen for sampling at random from the locational headquarters. The sampling units were households. The sample size per location was determined by the population size of babies 3 - 36 months old, obtained from the 1999 population and housing census [8]. A total of 242 households with babies of the age $3-36$ months were sampled. Questionnaires were administered to these mothers to obtain knowledge and practices of the mothers in regard to food handling and storage. The nutritional status of the children in question was assessed using clinical signs (diarrhoea, oedema) and anthropometric measurements. Their weights were recorded using the Saulter Scale while lying down length was taken using a tape. Diarrhoea was described as the clinical manifestation of expansion of the extracellular fluid volume. These data were used to group the children as; nourished, undernourished, kwashiorkor, marasmic kwashiorkor and marasmus using the Wellcome Classification of Severe ProteinEnergy Malnutrition. Weight for age, height for age and weight for height $Z$ scores were determined according to the median value of the World Health Organization reference population. The information on educational status and income of the parents was obtained through the questionnaire. About half a $\mathrm{kg}$ of flour samples used to feed the babies were obtained from the mothers and brought to the laboratory for analysis.

\section{Mycotoxin extraction}

The flour samples were analyzed using the procedure for aflatoxin described by the Association of Official Analytical Chemists (AOAC) [9]. Fifty grams of each sample in $250 \mathrm{ml}$ of a mixture of methanol and water (55:45) was blended for three minutes, at low speed. The supernatant fluid collected was subjected to a clean-up stage with sodium sulphate and $0.7 \mathrm{~g}$ florisil and washed with $20 \mathrm{ml}$ of a mixture of chloroform and methanol $(9: 1)$.

The aflatoxins were extracted with 50 $\mathrm{ml}$ acetone and water mixture $(99: 1)$. The 
eluate was then evaporated almost to dryness under gentle stream of nitrogen in a hot $\left(50^{\circ} \mathrm{C}\right)$ water bath. The residue was dissolved in $2 \mathrm{ml}$ of benzene-acetonitrite mixture $(49: 1)$ for spotting on TLC plates. The extracts were spotted alongside aflatoxin standards $B_{1}, B_{2} G_{1}$ and $G_{2}$. The identity of the aflatoxins in the extract were confirmed by the presumption test with sulphuric acid. The positive samples were respotted and the concentrations calculated using the method described by AOAC [9].

\section{Cultural studies and flour moisture content analysis}

Fungal flora of the flour was studied using both the direct and dilution techniques. Malt extract agar and potato dextrose agar was used. Before autoclaving, $7.5 \%$ sodium chloride was added to the media in order to inhibit fast growing "spreader" moulds. Antibiotic Chlortetracycline-HCL was added to the medium after sterilization to inhibit bacterial growth. The media was then plated, inoculated and maintained at room temperature $23^{\circ}-24^{\circ} \mathrm{C}$. Identification was done using taxonomic keys by Kozakiewicz [10], Pitt [11], and Gilman [12]. Flour shelf life was determined by culturing five of each of the most common flour types. The plates had five replicates. The samples were then shelved at room temperature and cultured after every seven days for six weeks. The moisture content of the flour was determined using the oven dry method recommended by the World Food Programme [13] and moisture content calculated using a formula given by the Kenya Bureau of Standards [14].

\section{Data Analysis and Management}

Data was entered into a microcomputer using SPSS for windows data entry programme. Data validation was done before analysis. For computation of anthropometric indices, e.g. weight-forage standard deviation ( $\mathrm{Z}$ or $\mathrm{SD}$ ) scores, ANTHRO programme (Centres for Disease Control/World Health Organization, 1990) was used. The computed indices were used as indicators of underweight based on -2 SD cut-off point. Another measure of nutritional status was based on the Wellcome Classification of Severe Protein-Energy Malnutrition was also computed using standard equations where Expected weight in $\mathrm{Kg}=$ (age in years $X 2)+8[15,16]$. Data analysis was done using SPSS for windows version 10.05. To test for significant differences between variables, Mann-Whitney U-test was used for non-normally distributed continuous data and Chi-Square or Fisher's exact probability test where applicable, for categorical data. Kolmogorov-Smimov test was used to test continuous data for normality. Significance level of 0.05 was used.

\section{Results}

Out of the 242 children covered by the study, $43.5 \%$ were males and $56.5 \%$ females giving a male : female ratio of $1: 1.3$. Prevalence of malnutrition was $34 \%$ for stunting (height for age $z$ score 2 ), $30 \%$ for being underweight (weight for age $\mathrm{z}$ score 2 ), and $6 \%$ for wasting (weight for height $z$ score 2). Of the wasted children, $53.8 \%$ were fed on aflatoxin contaminated flour compared with $27.7 \%$ of the normal children. This difference was highly significant $(\mathrm{P}=0.002)$. However the difference between the number of children fed on aflatoxin contaminated flour yet were normal with those that were stunted or underweight was not significant $(28.9 \%$ and $32.4 \%, \mathrm{P}=0.67 ; 27.3 \%$ and $41.4 \%, \mathrm{P}=0.13$ respectively).

The Wellcome Classification of Severe Protein Energy Malnutrition grouped 30.7\% of the children as not being well nourished (Table 1). Of these malnourished children, $60 \%$ had their weaning flour contaminated with aflatoxins while $27.4 \%$ of the normal children had their flour contaminated with aflatoxins. This difference was significant $(\mathrm{P}=0.004)$. Results of the aflatoxin analysis of flour samples are shown in Table 2 . Aflatoxins were detected in 70 (29\%) 
samples. Maize was the most frequently of flour $(\mathrm{P}=0.019)$. contaminated flour compared to other types

Table 1: The Nutritional Status of Children

\begin{tabular}{|c|c|c|c|c|c|c|c|}
\hline & \multirow[b]{2}{*}{$\begin{array}{l}\text { Nutritional } \\
\text { Status }\end{array}$} & \multicolumn{2}{|c|}{ Males } & \multicolumn{2}{|c|}{ Females } & \multicolumn{2}{|c|}{ Totals } \\
\hline & & $\begin{array}{l}\text { Number } \\
\text { of } \\
\text { children }\end{array}$ & $\begin{array}{c}\text { Percentage } \\
\%\end{array}$ & $\begin{array}{l}\text { Number } \\
\text { of } \\
\text { Children }\end{array}$ & $\begin{array}{l}\text { Percentage } \\
\%\end{array}$ & $\begin{array}{l}\text { Total } \\
\text { Number } \\
\text { of } \\
\text { Children }\end{array}$ & $\begin{array}{c}\text { Percentage } \\
\%\end{array}$ \\
\hline \multirow{5}{*}{$\begin{array}{l}\text { Welcome } \\
\text { Method of } \\
\text { Classification }\end{array}$} & Marasmus & 0 & 0 & 4 & 2.9 & 4 & 1.6 \\
\hline & Kwashiorkor & 8 & 7.4 & 5 & 3.8 & 13 & 5.4 \\
\hline & Marasmic- & 0 & 0 & 0 & 0 & 0 & 0 \\
\hline & $\begin{array}{l}\text { Under- } \\
\text { nutrition }\end{array}$ & 21 & 19.8 & 36 & 26.6 & 57 & 23.7 \\
\hline & Normal & 77 & 72.8 & 91 & 66.7 & 168 & 69.3 \\
\hline
\end{tabular}

Table 2: Flour types and aflatoxin contamination

\begin{tabular}{|l|l|l|l|l|l|}
\hline Flour content & $\begin{array}{l}\text { Number of } \\
\text { samples }\end{array}$ & $\begin{array}{l}\text { Percentage of total } \\
\text { with aflatoxins }\end{array}$ & Flour content & $\begin{array}{l}\text { Number of } \\
\text { samples }\end{array}$ & $\begin{array}{l}\text { Percentage of total } \\
\text { with aflatoxins }\end{array}$ \\
\hline 1 & 141 & 51.4 & $1,2,3,4$ & 4 & 0 \\
2 & 1 & 0 & $1,2,3,6$ & 1 & 0 \\
3 & 9 & 0 & $1,2,4,6$ & 5 & 1.4 \\
1,2 & 1 & 0 & $1,2,5,6$ & 3 & 4.3 \\
1,3 & 2 & 0 & $1,3,4,6$ & 1 & 1.4 \\
1,8 & 1 & 0 & $1,3,4,8$ & 1 & 0 \\
2,3 & 1 & 0 & $2,3,4,5$ & 1 & 0 \\
2,6 & 5 & 0 & $2,3,4,6$ & 1 & 0 \\
3,6 & 7 & 0 & $2,4,6,7$ & 1 & 0 \\
$1,2,6$ & 1 & 0 & $3,4,6,7$ & 1 & 0 \\
$1,2,7$ & 1 & 0 & $1,2,3,7$ & 1 & 0 \\
$2,3,6$ & 7 & $1,2,3,4,5$ & 17 & 7.1 \\
$2,4,7$ & 1 & $1,2,4,6,7$ & 1 & 1.4 \\
$2,6,7$ & 1 & 0 & $1,3,4,5,7$ & 14 & 18.6 \\
$3,4,7$ & 1 & 0 & $2,3,4,6,7$ & 7 & 10.0 \\
$3,5,6$ & 1 & 0 & $3,4,6,7,8$ & 1 & 0 \\
$2,3,9$ & 1 & 0 & & & \\
\hline
\end{tabular}

$\begin{array}{ll}1=\text { maize } & 6=\text { cassava } \\ 2=\text { sorghum } & 7=\text { beans } \\ 3=\text { millet } & 8=\text { rice } \\ 4=\text { groundnuts } & \\ 5=\text { dried fish } & \end{array}$


Table 3: Concentration of aflatoxins in contaminated gruel flour

\begin{tabular}{|c|c|c|c|c|c|c|c|c|c|}
\hline \multirow{2}{*}{$\begin{array}{l}\text { Gruel flour } \\
\text { ingredients }\end{array}$} & \multirow[t]{2}{*}{ Sample No. } & \multicolumn{8}{|c|}{ Aflatoxin detection and range of concentration } \\
\hline & & $\begin{array}{l}\mathrm{AFB} \\
1 \\
10- \\
20 \\
\mathrm{ppb} \\
+\end{array}$ & $\begin{array}{l}\text { AFB } \\
1 \\
21- \\
82 \\
\mathrm{ppb} \\
++\end{array}$ & $\begin{array}{l}\text { AFB } \\
2 \\
10- \\
20 \\
\mathrm{ppb}\end{array}$ & $\begin{array}{l}\mathrm{AFB} \\
2 \\
21- \\
82 \\
\mathrm{ppb} \\
\bullet\end{array}$ & $\begin{array}{l}\text { AFG } \\
1 \\
10- \\
20 \\
\mathrm{ppb}\end{array}$ & $\begin{array}{l}\text { AFG } \\
1 \\
21- \\
82 \\
\text { ppb } \\
\end{array}$ & $\begin{array}{l}\text { AFG } \\
2 \\
10- \\
20 \\
\text { ppb } \\
0\end{array}$ & $\begin{array}{l}\text { AFG } \\
2 \\
21- \\
82 \\
\text { ppb } \\
00\end{array}$ \\
\hline $\begin{array}{l}\text { Maize, } \\
\text { groundnuts, } \\
\text { millet, sorghum, } \\
\text { dried fish }\end{array}$ & $\begin{array}{l}22,152, \\
54 \\
36,168,54\end{array}$ & + & & $\diamond$ & & & $\square$ & & \\
\hline $\begin{array}{l}\text { Maize, } \\
\text { groundnuts, } \\
\text { Cassava, } \\
\text { sorghum }\end{array}$ & 149 & + & & & & & & & \\
\hline $\begin{array}{l}\text { Maize, } \\
\text { groundnuts, } \\
\text { millet, dried } \\
\text { fish, beans }\end{array}$ & $\begin{array}{l}48,89,112,157, \\
99,136,147,72,201 \\
8,68, \\
142,147 \\
158\end{array}$ & + & & $\bullet$ & & $\boldsymbol{\square}$ & & O & \\
\hline $\begin{array}{l}\text { Millet, sorghum, } \\
\text { Cassava }\end{array}$ & $\begin{array}{l}12 \\
16 \\
166 \\
\end{array}$ & $t$ & & $\diamond$ & & & $\mathbf{a}$ & & \\
\hline Maize & $\begin{array}{l}14,39,40,52,58,65 \\
87,107,117,128,154, \\
190,197,208,225, \\
77,86,155 \\
66,172,162,28,101 \\
121,19,84,47,7,10, \\
15,125,94,104 \\
37 \\
66,175,161\end{array}$ & + & ++ & $\bullet$ & $\diamond \bullet$ & 口 & & & $\odot \odot$ \\
\hline $\begin{array}{l}\text { Maize, sorghum, } \\
\text { dried fish, } \\
\text { cassava }\end{array}$ & $\begin{array}{l}31,96 \\
74\end{array}$ & & & & $\bullet$ & & & ○ & \\
\hline $\begin{array}{l}\text { Maize, millet, } \\
\text { groundnuts, } \\
\text { cassava }\end{array}$ & 242 & $\bar{t}$ & & & & & & & \\
\hline $\begin{array}{l}\text { Maize, sorghum, } \\
\text { groundnuts, } \\
\text { cassava, beans }\end{array}$ & 154 & + & & & & & & & \\
\hline $\begin{array}{l}\text { Sorghum, millet, } \\
\text { groundnuts, } \\
\text { cassava, beans }\end{array}$ & $\begin{array}{l}12,2,92,182,179 \\
149,133\end{array}$ & + & ++ & & & & & & \\
\hline
\end{tabular}

The occurrence of various aflatoxins in the different types of flour are shown in Table 3.
The concentration levels were as follows: thirty five samples were contaminated with 
aflatoxin B1 from $10-20 \mathrm{ppb}$, five samples had aflatoxin B1 from $21-82 \mathrm{ppb}$, fifteen samples with aflatoxin $\mathrm{B} 2$ from $10-20 \mathrm{ppb}$, six samples with aflatoxin B2 from $21-82$ $\mathrm{ppb}$, two samples with aflatoxin $\mathrm{Cl}$ from 10 $-20 \mathrm{ppb}$, three samples with aflatoxin G1 from $21-82 \mathrm{ppb}$, two samples with aflatoxin G2 $10-20 \mathrm{ppb}$ and lastly three samples with aflatoxin G2 $21-82 \mathrm{ppb}$. Three samples (no. 54, 66 and 147) contained two different aflatoxins B2 and $\mathrm{G} 1, \mathrm{~B} 2$ and $\mathrm{G} 2, \mathrm{~B} 1$ and $\mathrm{B} 2$ respectively.

Of the weaning flour $62 \%$ was purchased from the market while $38 \%$ was obtained from the farms. There was no correlation between the origin of the flour and aflatoxin contamination. The mothers stored the flour in different types of containers though plastic buckets were the most commonly used. Out of the 70 samples contaminated, with aflatoxins, $63 \%$ were stored in plastic buckets while $20.4 \%, 3.7 \%, 1.9 \%, 1.9 \%$, $1.9 \%$, and $7.4 \%$ were stored in polythene bags, metal buckets, manila sacks, earthen pots and reed baskets respectively. This difference was significant $(\mathrm{P}=0.05)$. The duration of storage of the flour for the households ranged from 1 day (32.8\%) through 1 week $(35.0 \%)$ to $2-5$ weeks $(32.2 \%)$. However only $20 \%$ of the mothers appreciated that their flour would deteriorate with time and therefore had spoilage signs (strongly sour or sharp flavour taste, offensive smell, color change, shiny surface and formation of lumps). The rest of the mothers used the flour for as long as it lasted. However none of them was aware of aflatoxins or mycotoxins. Their description of spoilage was close to mould growth and insect infestation. Of the mothers who had spoilage signs, 36 used the spoilt flour to cook food for adults, 10 used it to feed animals (chicken and goats) while 3 used it to make alcoholic brew. Cultural studies revealed that flour samples that were mixtures grew more fungal colonies than those made out of single grain type. As the storage time increased, the total number of fungal colonies increased as shown in Fig. 1.
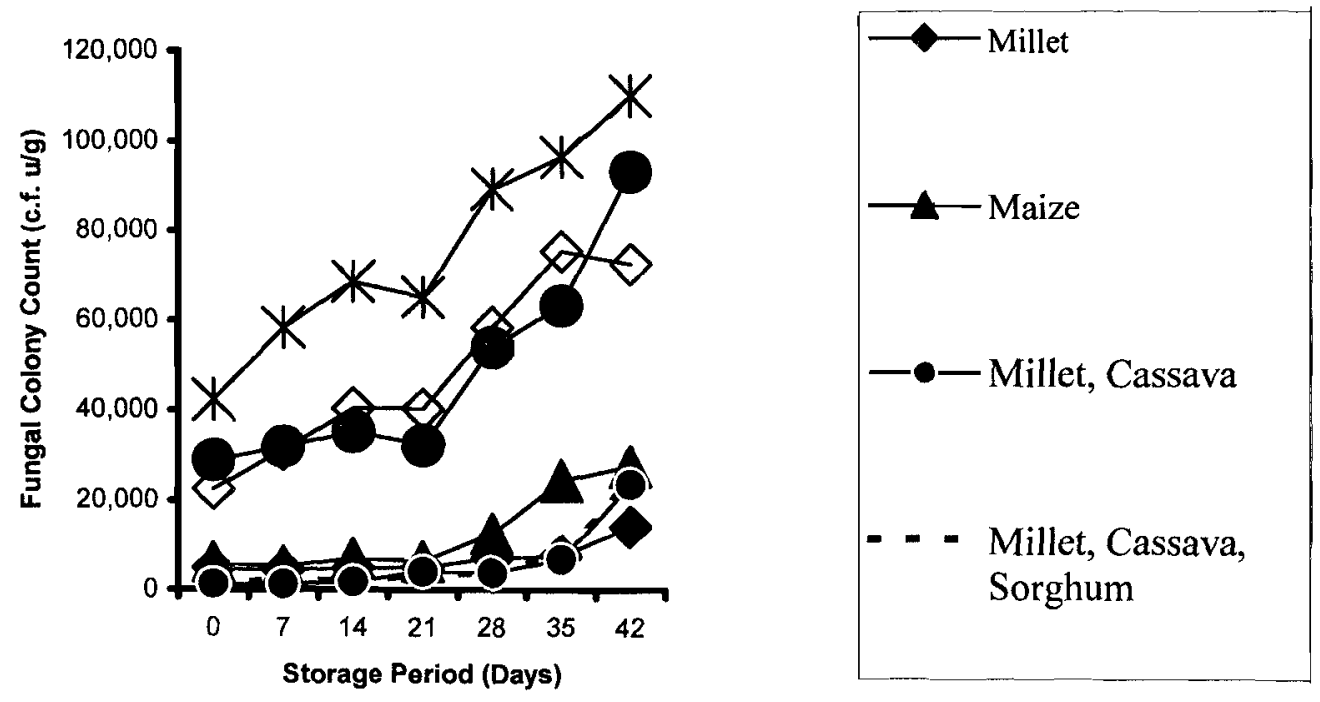

Figure 1: The relationship between storage period and the total number of fungal colonies 
Seven species of Aspergillus, four species of Penicillium were isolated from the weaning flour and these included toxin producers, Aspergillus flavus and A. parasiticus as shown in Table 4. Other moulds isolated were Curvularia spp., Fusarium, Mucor, Rhizopus nigricans and Trichoderma viride. Candida $\mathrm{sp}$. were also isolated from the flour. On average, the flour with aflatoxins had moisture content of $13.4 \%$ while those without had mean of $12.3 \%(\mathrm{P}<0.001)$. Samples with mixtures of nuts, green grams and beans had moisture content of more than $13 \%$. The number of fungal colonies also positively correlated with moisture content of flour (Fig. 2).

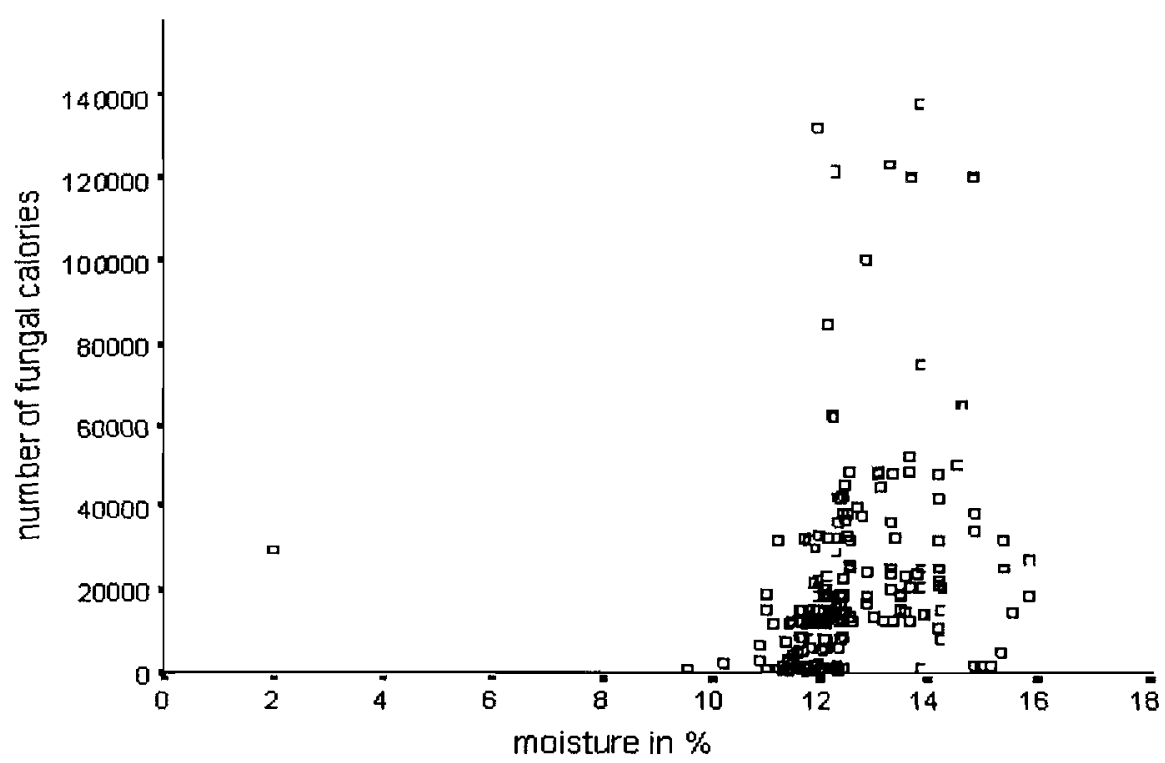

Fig. 2 The Relationship between moisture content and population of fungi (c.f.u. $/ g$ )

The variation was highly significant $(\mathrm{P}=$ 0.008 ). Table 5 shows the education and income of the father and mother. Both the income and education level did not vary significantly with child's nutritional status or presence of mycotoxins in flour. 
Table 4: Frequency of isolation of various fungi from the flour and in vitro production of aflatoxin by the indicated fungi

\begin{tabular}{|l|l|l|}
\hline Fungi isolated & $\begin{array}{l}\text { Frequency of } \\
\text { isolation }\end{array}$ & Aflatoxins \\
\hline Aspergillus flavus & 31 & + \\
A. parasiticus & 23 & + \\
A. terreus & 12 & - \\
A. humicola & 8 & - \\
A. niger & 16 & - \\
A. oryzae & 18 & - \\
A. sulphureus & 3 & - \\
Penicillium funiculosum & 12 & - \\
P. cyclopium & 65 & - \\
P. chrysogenum & 13 & - \\
Rhizopus nigricans & 4 & - \\
$P$. citrinum & 6 & - \\
Curvularia & 4 & - \\
Mucor sp. & 13 & - \\
Trichoderma viride & 9 & - \\
Fusarium solani & 4 & - \\
Yeasts & 13 & - \\
Sterile mycelium & 8 & \\
& & \\
\hline
\end{tabular}

Table 5: Education and income of parents

\begin{tabular}{|c|c|c|c|c|c|}
\hline \multicolumn{3}{|c|}{ Years of Formal Education } & \multicolumn{3}{|l|}{ Income } \\
\hline \multirow{2}{*}{$\begin{array}{l}\text { Number } \\
\text { of Years } \\
\text { of formal } \\
\text { education }\end{array}$} & \multicolumn{2}{|l|}{ Frequency } & \multicolumn{3}{|c|}{ Frequency } \\
\hline & $\begin{array}{l}\text { Male Head } \\
\text { of } \\
\text { Household }\end{array}$ & $\begin{array}{l}\text { Female } \\
\text { Head of } \\
\text { Household }\end{array}$ & $\begin{array}{l}\text { Income in } \\
\text { Kshs. }\end{array}$ & $\begin{array}{l}\text { Male Head } \\
\text { of } \\
\text { Household }\end{array}$ & $\begin{array}{l}\text { Female } \\
\text { Head of } \\
\text { Household }\end{array}$ \\
\hline $\begin{array}{l}\text { None } \\
1-8 \\
9-12 \\
13-14 \\
>14\end{array}$ & $\begin{array}{l}13 \\
113 \\
79 \\
17 \\
16\end{array}$ & $\begin{array}{l}16 \\
151 \\
58 \\
5 \\
3\end{array}$ & $\begin{array}{l}\text { None } \\
<\text { or }=1,000 \\
1,001-3,000 \\
3,001-5,000 \\
5,001- \\
10,000 \\
>10,000\end{array}$ & $\begin{array}{l}3 \\
61 \\
60 \\
53 \\
48 \\
13\end{array}$ & $\begin{array}{l}96 \\
65 \\
40 \\
17 \\
10 \\
5\end{array}$ \\
\hline
\end{tabular}




\section{Discussion}

This study confirms that malnutrition is a problem in Kisumu District with a percentage of $31 \%$ malnourished. The figures obtained for stunting and wasting were in line with World Bank [17] data for all subSaharan Africa. The study also reveals an association between exposure to aflatoxins in children and nutritional disorders (wasting- a reflection of acute malnutrition; kwashiorkor, marasmus and under-nutrition) in the region. Aflatoxin toxicity together with consumption of fungus affected food of poor nutritional quality, caused impaired growth of the children. This exposure starts straight from childhood and continues throughout life since the same grains are used for adult food. The whole population is therefore exposed to aflatoxins though children are more exposed since they, apart from being fed on milk, are exclusively fed on gruel made from these ground grains. Although the aflatoxin levels detected in the flour seem to fall within the acceptable limits (a few cases exceeding the acceptable limits) the safety of consumers of the flour is compromised by cumulative effects of the aflatoxin poisoning. These results agree with the findings of Hendrickse [18]. He reported kwashiokor and aflatoxin exposure as seasonally linked in tropical regions where aflatoxins are present. Adhikari et al. [19] also reported that children with kwashiorkor had tested positive for aflatoxin in blood and urine had statistically significant longer hospital stay and suffered from more infections. Wild and Hall [20] also suggested that aflatoxin acted in conjunction with kwashiorkor, possibly by immune suppression, to worsen the prognosis of hospitalized children. Pestka and Bondy [21] also stated that at lower doses, mycotoxins are immunosuppressive. For children between age $3-36$ months, it is the most critical time for mycotoxin exposure, when immune systems are still developing. This could also explain why cases of cancer and malignant diseases in children have increased in the region. Aflatoxin induced immunosupression may also contribute to the aggressive behavior of HIV infection in this region. The prevalence of HIV in 1990 was $19 \%$, but presently it is $35 \%$ (Source: National AIDS and STD Control Programme).

Poverty and ignorance emerged as the main factors contributing to aflatoxin exposure and precipitation of malnutrition. Kisumu District has been reported as having the highest incidence of absolute poverty, 64\%, in the country [7]. The population sampled was rated as poor according to the standards indicated in The Second Participatory Poverty Assessment Study in Kenya [22]. During sample collection, some households had less than half a kilogramme of flour and others had nothing left while $68 \%$ of the mothers earned up to Kenya shillings $1,000 /=$ per month, only $27 \%$ of the male household heads fell in this bracket. Most of the people lived in poor and untidy dwellings. This fact coupled with very little or no education $(7 \%$ of the mothers had no education while $64 \%$ had up to 8 years formal education) explained why the mothers were ignorant of proper child nutrition and food handling. The children were fed on flour of poor quality, mostly held in plastic buckets indefinitely. The buckets were stored in the kitchen close to the fireplace. Kisumu District, being hot and humid, condensation within these storage buckets would be unavoidable, thus producing moisture for fungal growth. Secondly, these buckets were hardly washed. This meant that the flour next to the wall of the buckets was last to exit the bucket and therefore stayed in the bucket longest. Flour in contact with the wall is also the only portion of the flour that changes appreciably due to temperature. These factors make flour in contact with the wall susceptible to moisture migration and mould growth. This means that the old flour will seed the fresher flour it contacts, increasing the chances of mould growth and mycotoxin formation. 
The cultural studies also revealed the presence of fungi that are known to produce other toxins apart from aflatoxins. Although only aflatoxins was assessed, mixtures of mycotoxin producing fungi were found in all samples (Table 4, Fig. 2). Members of the genera Penicillium and Fusarium are known to produce other groups of mycotoxins $[23,24]$. This suggests that mycotoxin mixtures are likely to occur in this region and that children are being exposed to multiple toxins. Such exposure may alter immunity in an additive or synergistic manner. The mixture of different foodstuffs; grains, legumes, groundnuts, dried fish ground together to form flour provided a rich substrate for fungal growth and possible production of mixtures of mycotoxins. Such mixtures also had higher moisture levels encouraging fungal growth, compared to flour with only one type of grain. Hell et al. [25] and Shetty and Bhat [26] reported simultaneous contamination of grain with both aflatoxin and fumonisin in southern Guinea savanna and India respectively. The poorest quality flour (whenever it could be spared) was used for animal feed or for making brew. This increased the chances of exposure of both children and adults to toxins since it is now known that when animals ingest contaminated feeds, some toxins can metabolize and thereby contaminate milk, meat and eggs [27].

\section{Conclusion}

Results of this study emphasize the need to develop strategies to reduce mycotoxin exposure, possibly involving interventions targeted at controlling mold growth. This can be achieved by educating mothers on the hazards of mycotoxins and factors that favour the growth of mycotoxin producing fungi. Mothers would be the targets for such training because childhood nutrition is a woman's problem in Kenya and is treated as such by health authorities who address their nutrition intervention efforts to mothers $[22,5]$. There is need to support and maintain nutrition surveillance through training and supervision of growth monitoring staff.
Public information campaigns about the importance of consuming only good quality grain and effective food preservation methods and shelf life should also be conducted. However, inducing behavioral change-thus enabling families to improve their diets even without additional income could be the most cost effective and practical way to improve nutritional status in this region [17]. We also recommend that regulatory standards on mycotoxins in the country be appropriately developed, maintained and enforced.

\section{Acknowledgement}

This work was done with funds from the Rockefeller Foundation.

\section{References}

1. Hall AJ and Wild CP. Epidemiology of aflatoxin-related disease. In: Eaton D. A. and Groopman J. D. Human health, veterinary and agricultural significance. San Diego, CA : Academic Press, 1994. p233-258.

2. Hendrickse RG. Of sick turkeys, kwashiorkor, malaria, perinatal mortality, heroin addicts and food poisoning: research on the influence of aflatoxins on child health in the tropics. Annals of Tropical Medicine and Parasitology. 1997.91 (7): 787-793.

3. Muraguri ML., Omukoolo C., Kenji G $M$. and Condier GA. A survey of mycotoxins in human and animals foods: Part 1. East African Medical Journal. 1981; 58 (7): 484 - 488.

4. Ngindu AM. and Arap Songok JK. Report on acute hepatitis caused by aflatoxin poisoning in Machakos district - Kenya. Division of disease control and research, Ministry of Health, Kenya. 1982.

5. Whyte SR and Kariuki PW. Malnutrition and gender relations in Western Kenya. Health Transition Review. 1991; 1 (2): 1-16.

6. Central Bureau of Statistics. First Report on Poverty in Kenya, July 1998. 76p. 
7. Government of Kenya. Interim Poverty Reduction Strategy Paper for the Period 2000-2003. June 2000. 102p.

8. Central Bureau of Statistics. Poverty Alleviation Programme Report. April, 2000.

9. Helrich K. Official Methods of Analysis Association of Official Chemists for Composition, Additives; Natural Contaminants. Volume Two. $15^{\text {th }}$ edition. 1990. The Association of Analytical Chemists Inc. Suite 4002200 Wilson Boulevard, Arlington, Virginia 2201, USA.

10. Kozakiewicz LZ. Aspergillus species in stored products. Mycological paper. Commonwealth Mycological Institute Institute. 1991. No. 161.

11. Pitt JT. The genus Penicillium and its teleomorphic states Eupenicillium and Talaramyces. Academic Press. London $1979.634 \mathrm{p}$.

12. Gilman JC. A manual of soil fungi. The Iowa State University Press. USA. 1957. p125-286.

13. World Food Programme; Food storage manual. Measurements of temperature. humidity and moisture content. Tropical Development and Research Institute, England. 1983. p13-21.

14. Kenya Bureau of Standards. Kenya Standard Specification for Dry Beans for Human Consumption. 1987. KS 01 456; 1987. 20p.

15. Underwood A.J. Experiments in ecology. Their logical design and interpretation using analysis of variance. Cambridge University Press. 1997, 504p.

16. Wellcome Trust Working Party Classification of Infantile Malnutrition. Lancet. 1970; 2: 302-303.

17. World Bank. World Development Report: Investing in Health. Oxford University Press, Inc. New York. 1993. $329 \mathrm{p}$.

18. Hendrickse RG. Clinical implications of food contamination by aflatoxins. Annals of the Academy of Medicine, Singapore. 1991; 20 (1): $84-90$.
19. Adhikari M; Ramjee G; and Berjak Pin, Aflatoxin, Kwashiorkor, and morbidity. Natural Toxins. 1994; 2 (1): 1-3.

20. Wild CP and Hall AJ. Epidemiology of mycotoxin-related disease. The Mycota VI. Human and Animal Relationships. Howard/Miller (eds.). Springer Verlag, Berlin. 1996. p213-225.

21. Pestka JJ and Bondy GS. Immunotoxic Effects of Mycotoxins. In: Mycotoxins in Grain, Compounds other than Aflatoxin. J. D. Miller, ed. Eagan Press, St. Paul MN. 1994. p339 358.

22. Government of Kenya. The Second Participatory Poverty Assessment Study - Kenya. Volume 1. Report prepared by AMREF and the Human Resources Social Services Department of the Office of the Vice-President and Ministry of Planning and National Development. 1997. 82p.

23. Abraham D and D'Mello, JPF. Toxicants of the genus Penicillium. Handbook of plant and fungal toxicants. 1997. CRC Press: Boca Raton, USA.

24. Gao HP and Yoshizawa T. Further study on Fusarium mycotoxins in corn and wheat from a high-risk area for human oesophageal cancer in China. Mycotoxins. 1997; 45: 51-55.

25. Hell K; Setamou M; Visconte A; and Cardwell KF. (ed.) Mycotoxins in Foods in Africa. Proceedings of the Benin workshop. Nov. 6 - 10, 1995. IITA, 1996. 100p.

26. Shetty PH. and Bhat RV. Natural occurrence of fumonism B1 and its co-occurrence with aflatoxin B1 in Indian sorghum, maize and poultry feeds. Journal of Agricultural \& Food Chemistry. 1997; 45 (6): 2170 $-2173$.

27. Hendricks IV and Stolof L. Aflatoxin residues from contaminated feed in 


\section{RESEARCH ARTICLES}

edible tissues of food-producing animals. In Rodricks, C. W. Hesseltine and Mehlmon, eds., Mycotoxins and animal health. Park Forest Hills, Illinois,

Pathotox Publishers Inc. 1977; p67-69 